\title{
Energy Metabolism of the Roe Deer
}

\author{
January WEINER
}

Weiner J., 1977: Energy metabolism of the roe deer. Acta theriol., 22, 1: 3-24 [With 5 Tables \& 9 Figs.].

Energy metabolism of the roe deer Capreolus capreolus $(\mathrm{L}$ in $\mathrm{n}$ a e $\mathrm{us}$, 1758) was investigated by means of the respirometric method. The level of metabolism in roe deer is similar to that of other wild ruminants but higher than the mean interspecies metabolism of mammals. Fasting heat production $(F H P)$ shows seasonal variations, being the highest during spring molting season, slightly lower in summer and the lowest in winter: 117.0, 99.4 and $91.3 \mathrm{kcal} \times \mathrm{kg}^{-0.75} \times$ day $^{-1}$, respectively. In spring and summer the metabolism increases at lower temperatures: FHP $\left(\mathrm{kcal} \times \mathrm{kg}^{-0.75} \times \mathrm{day}^{-1}\right)=181.5-5.32 t$ (where $t={ }^{\circ} \mathrm{C}$ ). Resting metabolism of non-fasted animals (RHP) is higher than FHP by $25-30 \%$ and this difference represents the specific dynamic action of food (SDA). Motoric activity causes a rise of metabolism by $9-210 \%$, the cost of maintaining of upright position being equal to $1.1 \mathrm{kcal} \times \mathrm{kg}-0.75 \times$

$\times \mathrm{hr}^{-1}$. Resting metabolism of fawns up to 80 days of life is linearly correlated with their body weight $(W, \mathrm{~kg}): R H P=73.53 \mathrm{~W}$ (where $R H P=$ $=\mathrm{kcal} \times$ animal $^{-1} \times$ day $\left.^{-1}\right)$. $R H P$ reaches the highest values on 7 th day of life. In fawns 6 to 8 month old $F H P$ amounts to $109.9 \mathrm{kcal} \times \mathrm{kg}^{-0.75} \times$ $X_{\text {day }^{-1}}$, and $R H P$ is higher by $22 \%$. The mean respiratory quotient (R.Q.) was equal to 0.82 ; the lowest values $(0.79)$ were observed in fasting and resting animals, while the highest $(0.86)$ in active nonfasting ones.

[Dept. Animal Ecol., Jagiellonian Univ., Krupnicza 50, 30-060 Kraków]

\section{INTRODUCTION}

Population of roe deer, Capreolus capreolus ( $\mathrm{L}$ in n a e u s, 1758) play an important role in both energy flow and matter circulation in almost all European forest ecosystems (B o b e k et al., 1974; G rodziński, 1975). Moreover, roe deer belongs to game and is a species of direct economical value, being at the same time potentially responsible for damages in forest economy.

Studies of the role of roe deer in forest ecosystems and optimalization of hunting economy must be based on the knowledge of energy and food requirements of these animals ( $\mathrm{Grodzinski,1975).} \mathrm{Hitherto}$ roe deer were rarely the subject of ecological-physiological studies.

1 Praca została zrealizowana w ramach problemu węzłowego 09.1.7 koordynowanego przez Instytut Ekologii PAN. 
The data on their energy metabolism are totally lacking, while the investigations on consumption and digestibility of natural food in this species were carried out in a rather narrow scope (D ro żd $\dot{z}$ \& O siecki, 1973; D rożdż et al., 1975; E is f eld, 1974; Ellen berg, 1974). Energy metabolism was studied only in a few species of American deer, red deer and reindeer (e.g. Brockway \& Maloiy, 1967; Silver et al., 1969; 1971; N ordan et al., 1970; M c Ew a n, 1970).

The present study was aimed at elucidating energy metabolism of roe deer in a degree enabling construction of the daily energy budget of these animals (Weiner, 1975). The selection of the respirometric method ensured a sufficient accuracy for investigation of a relationship between metabolism rate and various external factors and physiological state of animals. Quantitative assessment of such relationships is essential for evaluation of energy requirements of roe deer in natural conditions.

\section{MATERIAL AND METHODS}

All the respirometric measurements were carried out on tamed animals reared in captivity from birth. The animals were kept in a large pen (ca. 0.5 ha) covered with forest and situated in Kraków Zoological Garden. During the experiments selected animals stayed in a small pen $\left(120 \mathrm{~m}^{2}\right)$ at the University Campus. The whole herd of roe deer during two years of experiments numbered 27 individuals, out of which 16 most tamed animals were used for respinometric measurements ( $4 \sigma^{7} \sigma^{7}, 8$ 우, 4 fawns in the age of $1-80$ days). The adult roe deer were weighed with the accuracy of $0.5 \mathrm{~kg}$, and fawns with the accuracy up to $0.01 \mathrm{~kg}$.

For measuring metabolic rate a flow respirometer "Spirolyt (Junkalor) was used with a paramagnetic analyzer of changes of oxygen content and diaferometric measurement of carbon dioxide content. The animals stayed in an air-conditioned chamber ca 8001 in volume (Fig. 1), through which the air flowed at the speed of $1800-20001 \times \mathrm{hr}^{-1}$. The chamber was equipped with a device registering position of animals during the experiment (photocell), an electronic detector of deviations from the programmed air flow and a treadmill. Metabolism of fawns was measured in a smaller plexiglass chamber, 601 in volume, with the air flow of $150-4001 \times \mathrm{hr}^{-1}$. At those flow rates of air through the employed chambers the changes in the content of oxygen and carbon dioxide did not exceed $2 \%$, and thus could not produce any physiological disturbances in the animals (B l a x te r, 1962; M c Ewan, 1970; Nordan et al., 1970).

Changes in the concentration of oxygen and carbon dioxide, and in position of the animal in the chamber, were continuously registered throughout the experiment. The runs lasted from two to eight hours and were always carried out between $9^{00}$ and 1700 . Before starting the proper experiment the animals stayed in the chamber for at least two hours in order to adapt them to experimental conditions and ambient temperature. During computation of the results of gasometric measurements into energy values the caloric equivalent of oxygen was determined independently for each measurement according to the observed respiratory quotient (R.Q.).

The following standard measures of metabolism were employed in the exferiments: 
(I) fasting heat production, $F H P$ (=fasting metabolic rate, SMR). A postabsorptive state in the examined animals is an essential condition for this measurement. This was achieved by fasting of roe deer during $48 \mathrm{hr}$, which leads to a decrease of R.Q. below 0.8. According to B la xter (1962) total emptying of the intestinal tract requires so long time that it causes physiological disturbances, hence fasting for 2 days is generally regarded as sufficient. A similar procedure in the studies of wild ruminants was employed by Silver et al. $(1969,1971)$, We sle y et al. $(1970,1973)$, and by others.

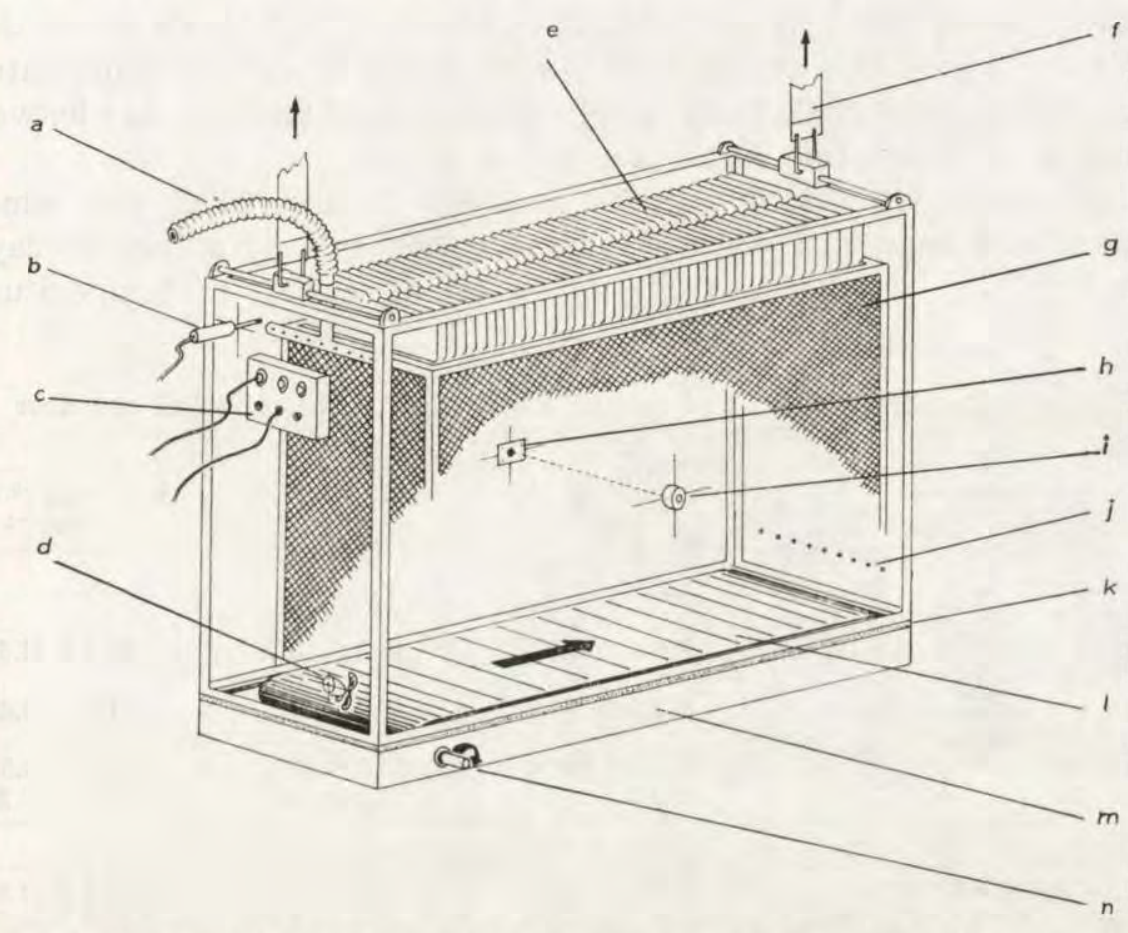

Fig. 1. Respirometric chamber for measuring metabolism of adult roe deer.

$\mathrm{a}$ - outlet of air-connection with a respirometer, $\mathrm{b}$ - temperature indicator, $\mathrm{c}$ - panel of electric connections, $d$ - ventilating fan, e - cooling device, $f$ - tape of the riser, $g$ - cage, $h$ - photocell, $i$ - infrared lamp, $j$ - inlet of air, $\mathrm{k}$ - gasket, $\mathrm{l}$ - treadmill, $\mathrm{m}$ - mount, $\mathrm{n}$ - shaft of the driving gear of treadmill.

(II) resting heat production, RHP (=resting metabolic rate, RMR) was measured in non-fasted animals with minimal motoric activity. Such metabolism includes calorigenic effect of food.

(III) costs of locomotor activity correspond to the difference between RHP and metabolism during a defined motoric activity (e.g. standing, movements, etc.), measured both in fasted and non-fasted animals.

(IV) costs of thermoregulation correspond to the difference between fasting metabolic rate measured within the thermoneutral zone, and metabolism at lower ambient temperatures.

The results of measurements were elaborated statistically according to $\mathrm{Z}$ a $\mathrm{r}$ (1974). Significance of linear regression coefficients and differences between 
regressions and mean values were evaluated by $t$-test, and significance of curvilinear regression was evaluated by analysis of variance. All the confidence intervals for means and regressions were calculated at the confidence level of $95 \%$.

\section{RESULTS}

\section{Fasting Metabolism (FHP) of Adult Animals}

In summer (June-August) 1973 and 197419 series of measurements of fasting metabolism were carried out in 5 adult individuals of roe deer $\left(2 \sigma^{x} \sigma^{x}\right.$ and 3 우). The measurements were made at ambient temperature ranging from 3 to $26^{\circ} \mathrm{C}$. Body weight of examined animals was between 18 and $24 \mathrm{~kg}$, amounting on the average to $21.5 \mathrm{~kg}$.

FHP measured in temperatures between 17 and $26^{\circ} \mathrm{C}$ was almost constant and amounted on the average to $990.5 \mathrm{kcal} \times \mathrm{animal}^{-1} \times \mathrm{day}^{-1}$ (99.4 kcal $\times \mathrm{kg}^{-0.75} \times$ day $^{-1}$, Table 1). FHP measured in temperatures

Table 1

Fasting metabolism (FHP) and resting metabolism (RHP) of adult roe deer (mean $\pm 95 \%$ confidence interval).

\begin{tabular}{|c|c|c|c|}
\hline Season & $\underset{\text { day }^{-1}}{\operatorname{kcal} \times \underset{\text { animal }}{-1} \times}$ & $\underset{\mathrm{day}^{-1}}{\mathrm{keal} \times \mathrm{kg}^{-1} \times}$ & $\begin{array}{c}\mathrm{kcal} \times \mathrm{kg}^{-0.75} \times \\
\mathrm{day}^{-1}\end{array}$ \\
\hline \multicolumn{4}{|c|}{ FHP } \\
\hline $\begin{array}{l}\text { SUMMER } \\
\text { (temp. } 17^{\circ}-20^{\circ} \mathrm{C} \text { ), } \mathrm{N}=10\end{array}$ & $990.5 \pm 140.6$ & $46.1 \pm 5.5$ & $99.4 \pm 11.6$ \\
\hline $\begin{array}{l}\left.\text { (temp. } 9^{\circ}-22^{\circ} \mathrm{C}\right), \mathrm{N}=14 \\
\text { MOLTING SEASON }\end{array}$ & $858.8 \pm 35.9$ & $46.2 \pm 4.1$ & $91.3 \pm 5.4$ \\
\hline $\begin{array}{ll}\left.\text { (temp. } 10^{\circ} \mathrm{C}\right), & N=4 \\
\left.\text { (temp. } 20^{\circ} \mathrm{C}\right), & N=4\end{array}$ & $\begin{array}{l}1233.0 \pm 130.7 \\
1019.0 \pm 192.1\end{array}$ & $\begin{array}{l}69.8 \pm 12.1 \\
57.0 \pm 8.6\end{array}$ & $\begin{array}{l}142.1 \pm 14.5 \\
117.0 \pm 13.2\end{array}$ \\
\hline \multicolumn{4}{|c|}{ RHP } \\
\hline $\begin{array}{l}\text { SUMMER, } N=3 \\
\text { WINTER, } N=8\end{array}$ & $\begin{array}{l}1280.0 \pm 52.9 \\
1072.7 \pm 183.1\end{array}$ & $\begin{array}{l}55.1 \pm 5.0 \\
49.6 \pm 5.9\end{array}$ & $\begin{array}{l}129.8 \pm 22.9 \\
113.8 \pm 18.1\end{array}$ \\
\hline
\end{tabular}

between 3 and $17^{\circ} \mathrm{C}$ showed a strong negative correlation with ambient temperature $(r=-0.90 ; p<0.001)$. The relationship between $F H P$ and ambient temperature in the range of 3 to $17^{\circ} \mathrm{C}$ can be expressed in the form of rectilinear regression:

$$
F H P=181.5-5.32 t
$$

where: $F H P$ - kcal $\times \mathrm{kg}^{-0.75} \times$ day $^{-1}, t$ - ambient temperature ${ }^{\circ} \mathrm{C}$ (Fig. 2). The coefficient of regression shows a strong significance $(p<0.001)$ with the confidence interval of \pm 1.36 ; the regression explains $81 \%$ variability of FHP.

The results of measurements of FHP in summer season did not reveal significant differences associated with sex, nor any relationship between metabolic rate and body weight.

In two winter seasons (December-February) 14 measurements of 
FHP were made in 4 adult roe deer $\left(1 \sigma^{x}, 3\right.$ 우) with the mean body weight of $19.0 \mathrm{~kg}$ (range of variability $15.5-22.5 \mathrm{~kg}$ ). In the range of temperatures between 9 and $22^{\circ}$ no relationship was found between metabolic rate and ambient temperature.

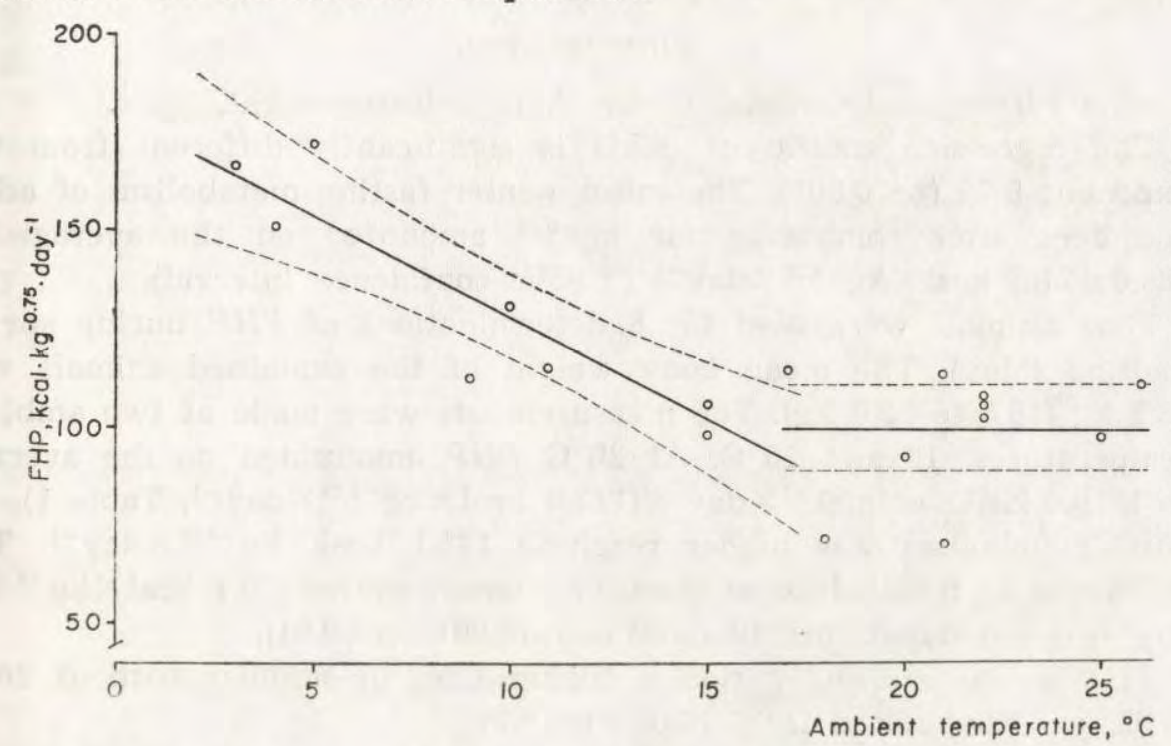

Fig. 2. Relationship between fasting metabolism $(F H P)$ of roe deer and ambient temperature.

Continuous line $-F H P$; broken line $-95 \%$ confidence interval. $F H P=181.5-5.32 t$, for $t<17^{\circ} \mathrm{C}$.

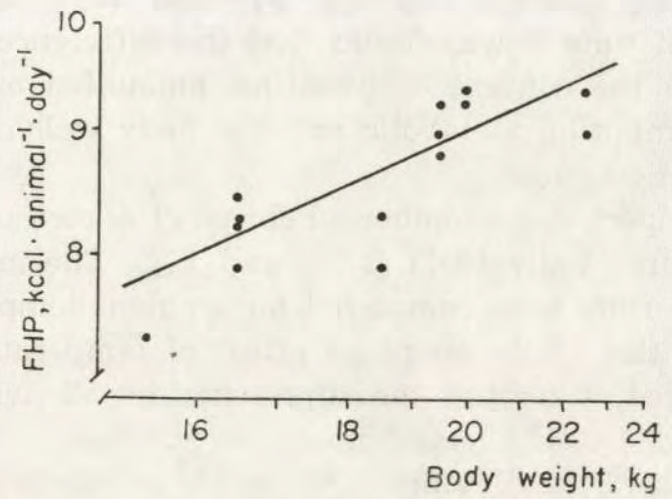

Fig. 3. Relationship between FHP of adult roe deer and their body weight in winter (doubly logarithmic scale). $F H P=193.6 \mathrm{~W} 0.51$.

The mean rate of fasting metabolism in winter $(\mathrm{N}=14)$ was slightly lower than in summer: $91.3 \mathrm{kcal} \times \mathrm{kg}^{-0.75} \times$ day $^{-1}$ (Table 1), but the difference $\left(8.1 \mathrm{kcal} \times \mathrm{kg}^{-0.75} \times\right.$ day $\left.^{-1}\right)$ was statistically not significant $(0.1<$ 
$<p<0.5$ ). Winter FHP of roe deer showed a strong relationship between metabolism and body weight (Fig. 3). The regression describing the relationship between metabolism and body weight calculated by double logarithmic transformation appears in the following formula:

$$
F H P=193.6 \text { W } 0.51
$$

where: $F H P-$ kcal $\times$ animal $^{-1} \times$ day $^{-1}, W-$ body weight, $\mathrm{kg}$.

The regression coefficient $(0.51)$ is significantly different from the exponent $0.75(p<0.001)$. The mean winter fasting metabolism of adult roe deer after computing for $\mathrm{kg}^{-0.51}$ amounted on the average to $188.0 \pm 21.5 \mathrm{kcal} \times \mathrm{kg}^{-0.51} \times$ day $^{-1}\left( \pm 95^{\circ} \%\right.$ confidence interval).

Four animals were used for 8 determinations of FHP during spring molting (May). The mean body weight of the examined animals was $18.5 \mathrm{~kg}$ (16.5 to $22.0 \mathrm{~kg}$ ). The measurements were made at two ambient temperatures: 10 and $20^{\circ} \mathrm{C}$. At $20^{\circ} \mathrm{C} \mathrm{FHP} \mathrm{amonunted} \mathrm{on} \mathrm{the} \mathrm{average}$ to $1019.0 \mathrm{kcal} \times \mathrm{animal}^{-1} \times$ day $^{-1}\left(117.0 \mathrm{kcal} \times \mathrm{kg}^{-0.75} \times\right.$ day $^{-1}$, Table 1$)$. At $10^{\circ} \mathrm{C}$ metabolism was higher reaching $142.1 \mathrm{kcal} \times \mathrm{kg}^{-0.75} \times \mathrm{day}^{-1}$. The difference in metabolism at these two temperatures $\left(25.1 \mathrm{kcal} \times \mathrm{kg}^{-0.75} \times\right.$ day $\left.^{-1}\right)$ is statistically highly significant $(0.001<p<0.01)$.

FHP in the molting period is higher than in summer both at $20^{\circ} \mathrm{C}$ $(0.02<p<0.05)$ and at $10^{\circ} \mathrm{C}(0.05<p<0.1)$.

\section{Resting Metabolism (RHP) of Adult Roe Deer}

Resting metabolism was measured in non-fasted animals. On the basis of weighing animals during FHP and RHP determinations in short intervals of time it was found that the difference in body weight, corresponding to the content of intestine, amounted on the average to $1.7 \mathrm{~kg}$. When computing metabolic rate for body weight unit the weight of fasted animals was used.

In the winter period (December-February) 8 measurements of RHP were made in three individuals $\left(2\right.$ 우 and $\left.1 \sigma^{7}\right)$. The mean body weight was $21.5 \mathrm{~kg}$. The runs were completed for ambient temperatures between 10 and $24^{\circ} \mathrm{C}$. In the whole range no effect of temperature on metabolic rate was observed, thus the measurements in all temperatures were analyzed jointly. Resting metabolism of non-fasted roe deer ranged from 838.3 to $1357.2 \mathrm{kcal} \times \mathrm{animal}^{-1} \times \mathrm{day}^{-1}$, amounting on the average to $1072.7 \mathrm{kcal} \times \mathrm{animal}^{-1} \times$ day $^{-1}$ (i.e. $113.8 \mathrm{kcal} \times \mathrm{kg}^{-0.75} \times$ day $^{-1}$, Table 1).

RHP of adult roe deer measured in summer (August) was higher than in winter (Table 1) reaching the average value of $129.8 \mathrm{kcal} \times{ }^{-0.75} \times \mathrm{day}^{-1}$. The difference, equal to $16.0 \mathrm{kcal} \times \mathrm{kg}^{-0.75} \times$ day $^{-1}$ is, however, statistically not significant $(0.1<p<0.5)$. In both seasons the $R H P$ values of adult roe deer did not show any relationship with body weight. 


\section{Metabolism during Pregnancy and Lactation}

In March 1973 a single measurement of fasting metabolism was determined in a pregnant female (body weight $23.5 \mathrm{~kg}$ ). FHP in this period amounted to $103.9 \mathrm{kcal} \times \mathrm{kg}^{-0.75} \times$ day $^{-1}$ (Table 2), hence it was slightly higher than winter metabolism (the difference is $12.6 \mathrm{kcal} \times$ $\mathrm{kg}^{-0.75} \times \mathrm{day}^{-1}$ ). In a later period of pregnancy metabolic determinations. were not carried out in order not to disturb the doe.

In June and July 1973 RHP was determined in the same female during intense lactation (11th and 30th day). The doe nursed two fawns. On 11th day of lactation her body weight was $24 \mathrm{~kg}$ and metabolism reached

Table 2

Metabolism of roe deer during pregnancy and lactation.

\begin{tabular}{|c|c|c|c|c|c|}
\hline $\begin{array}{l}\text { Period of } \\
\text { measurement }\end{array}$ & Item & $\begin{array}{l}\text { Body } \\
\text { weight }\end{array}$ & $\underset{\text { day }^{-1}}{\text { kcal }} \times \underset{\text { animal-1 }}{\operatorname{an}}$ & $\underset{\mathrm{day}^{-1}}{\mathrm{kcal} \times \mathrm{kg}^{-1} \times}$ & $\underset{\text { day }-1}{\mathrm{kcal} \times \mathrm{kg}^{-0.75} \times}$ \\
\hline $\begin{array}{l}\text { Pregnancy } \\
\text { 8. month }\end{array}$ & $\begin{array}{l}\quad F H P \\
\text { Difference } \\
\text { in relation } \\
\text { to winter } \\
\text { FHP }\end{array}$ & 23.5 & 1112.6 & $\begin{array}{r}47.3 \\
1.1\end{array}$ & $\begin{array}{r}103.9 \\
12.6\end{array}$ \\
\hline $\begin{array}{l}\text { Lactation } \\
\text { 11. day }\end{array}$ & \begin{tabular}{l}
\multicolumn{1}{c}{$R H P$} \\
Difference \\
in relation \\
to summer \\
RHP
\end{tabular} & 24.0 & 2447.2 & $\begin{array}{l}102.0 \\
49.9\end{array}$ & $\begin{array}{l}226.6 \\
96.8\end{array}$ \\
\hline $\begin{array}{l}\text { Lactation } \\
\text { 30. day }\end{array}$ & \begin{tabular}{l}
\multicolumn{1}{c}{ RHP } \\
Difference \\
in relation \\
to summer \\
RHP
\end{tabular} & 22.5 & 2565.3 & $\begin{array}{l}69.6 \\
16.8\end{array}$ & $\begin{array}{r}152.2 \\
22.4\end{array}$ \\
\hline
\end{tabular}

$226.6 \mathrm{kcal} \times \mathrm{kg}^{-0.75} \times \mathrm{day}^{-1}$ (Table 2). However, during the experiment the doe preserved upright position. On 30th day of lactation body weight of the female decreased to $22.5 \mathrm{~kg}$, and resting metabolism was then equal to $152.2 \mathrm{kcal} \times \mathrm{kg}^{-0.75} \times \mathrm{day}^{-1}$. The results of the two measurements. conspicuously exceed the mean RHP in summer $(p<0.001$, Table 2$)$.

\section{Energy Costs of Locomotor Activity}

In standard measurements of FHP and RHP only the periods of total rest (lying position) were taken into account, as corresponding to the lowest oxygen consumption. During most of the runs roe deer developed periodically some motoric activity which increased their metabolism by 9 to $210 \%$ (Fig. 4 ).

Small slow movements in lying position increased metabolism by not 
more than $9 \%$. The lowest level of metabolism in standing position was higher than during rest by approximately $22 \%$, and the cost of this activity amounted on the average to $1.1 \mathrm{kcal} \times \mathrm{kg}^{-0.75} \times \mathrm{hr}^{-1}(\mathrm{~N}=11$, $\mathrm{SE}= \pm 0.12$ ). Slow movements in standing position caused a rise of

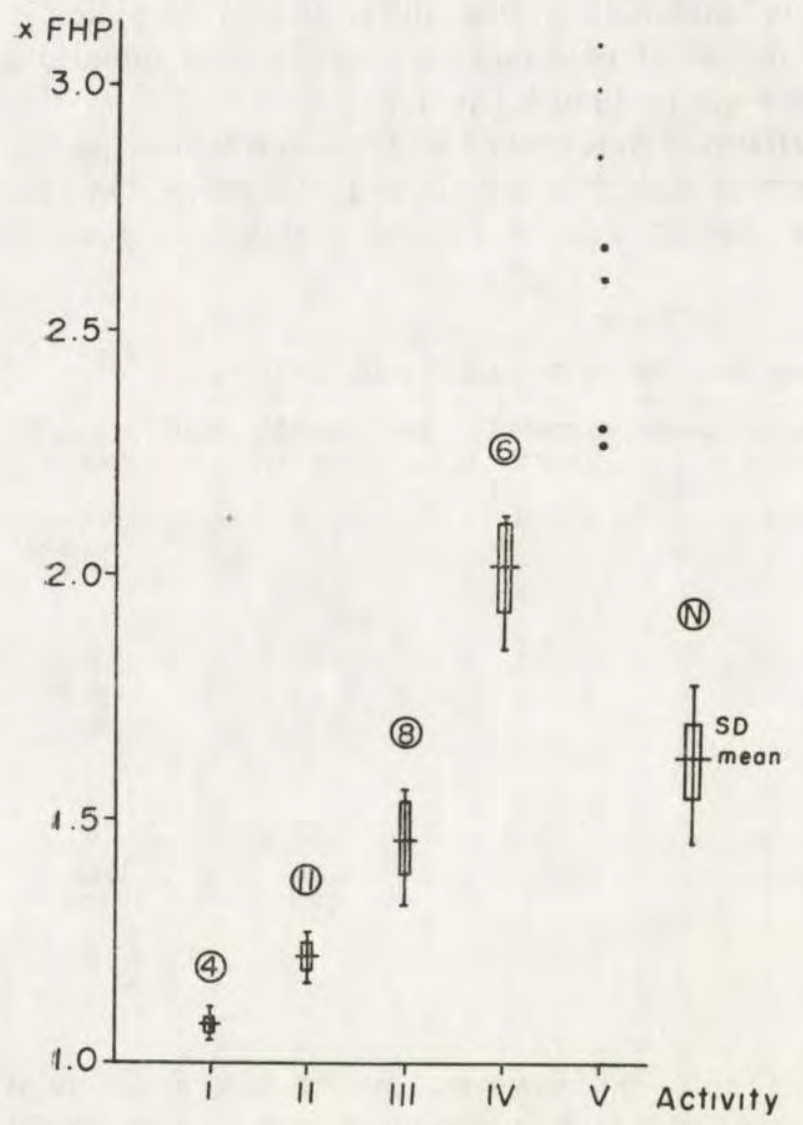

Fig. 4. Relationship between metabolism (expressed as multiplicity of $F H P$ ) and motoric activity of roe deer.

I - slow movements in lying position, II - standing, III slow movements in standing position, IV - walking, turning round the cage, $\mathrm{V}$ intense activity, stress. The results of $\mathrm{V}$ based on single measurements.

metabolism rate by more than $45 \%$, and fast movements of turning around the cage - by more than $100 \%$. The highest activity, anxiety, ect., resulted in the increase of metabolism by $130-210 \%$ (Fig. 4).

\section{Metabolism of Fawns below 80th Day of Life}

In four fawns born in captivity (two single litters and one twin litter) resting metabolism (RHP) was measured during first 80 days of life. On the whole 31 measurements of RHP were made, and out of this number 22 fell for the first month of life. All runs were at ambient temperature of 22 to $24^{\circ} \mathrm{C}$. 
The increase of body weight of fawns from 3 to 80 days of life is shown in Fig. 5. Changes in body weight of fawns in this period are expressed by a second order regression equation:

$$
W=1.5098+0.1506 X-0.000676 X^{2}
$$

where: $W$ - body weight, kg; $X$ - age, in days after birth $(p<0.001)$.

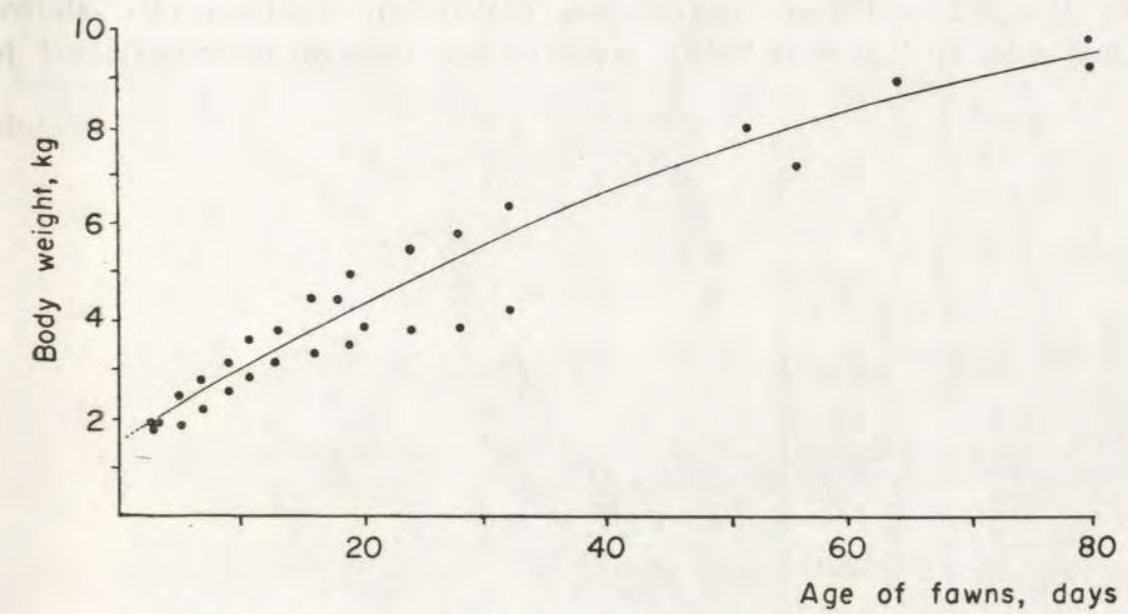

Fig. 5. Growth curve of fawns during first 80 days of life: $W=1.5098+0.1506 X-0.000676 X^{2}$.

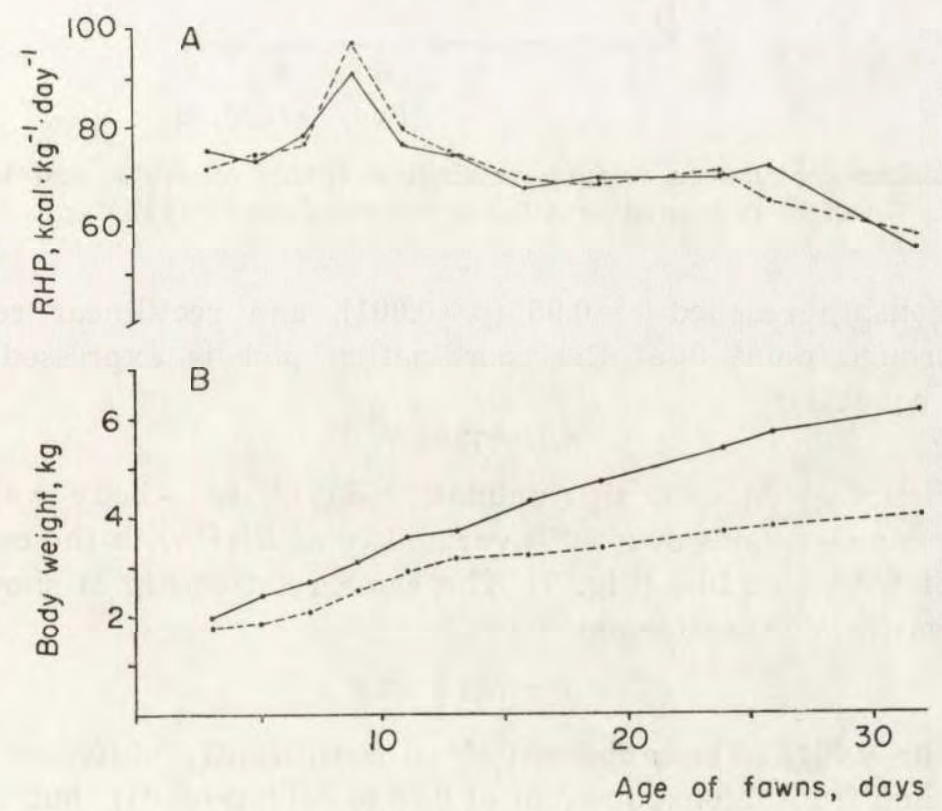

Fig. 6. Changes in resting metabolism (A) and body weight (B) in two fawns during first month of life. 
The course of changes of resting metabolism jointly with actual changes of body weight were continuously followed in two fawns ( $\sigma^{*}$ and $q$ ) during the first month of life (Fig. 6). In this period RHP ranged from 54.5 to $91.1 \mathrm{kcal} \times \mathrm{kg}^{-1} \times \mathrm{day}^{-1}$, with the maximum occurring in both animals on 7 th day. On 80 th day RHP amounted on the average to $80.1 \mathrm{kcal} \times \mathrm{kg}^{-1} \times \mathrm{day}^{-1}$, and body weight was then equal to $9.3 \mathrm{~kg}$. During the whole 80 -day period the resting metabolism rate showed a strong relationship with body weight. The correlation coefficient for

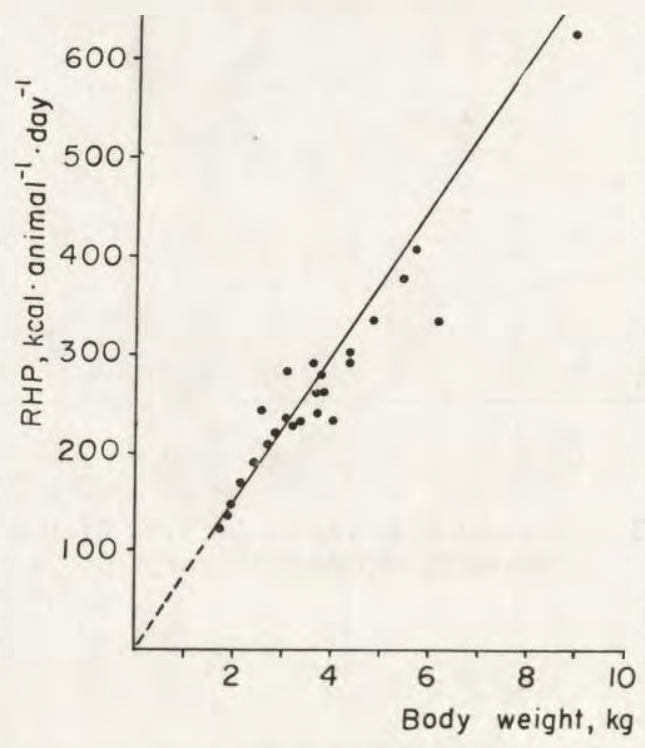

Fig. 7. Relationship between resting metabolism (RHP) of fawns and their body weight presented as a linear function: $R H P=73.53 \mathrm{~W}$.

this relationship reached $r=0.95(p<0.001)$, and rectilinear regression drawn through point 0 of the coordination plot is expressed by the following equation:

$$
\text { RHP }=75.53 \mathrm{~W}
$$

where $R H P$ is given in kcal $\times$ animal $^{-1} \times$ day $^{-1}, W-$ body weight, $\mathrm{kg}$. This regression explains over $90 \%$ variability of $R H P$ with the confidence interval of $95 \%=b \pm 10.5$ (Fig. 7). The same relationship is shown after double logarithmic transformation:

$$
R H P=79.4 W^{0.9313}
$$

$(r=0.96, p<0.001)$. The exponential is significantly different from 0 $p<0.001)$ and from the exponential of $0.75(0.001<p<0.01)$, but not from the exponential equal to $1(0.1<p<0.5)$, Fig. 8 . 


\section{Metabolism of Half-year-old Fawns}

During winter (January - beginning of March) measurements of FHP and RHP were made in fawns 6 to 9 months old. Body weights of examined individuals were equal to $13.5 \mathrm{~kg}$ on the average, ranging from 11.5 to $15.0 \mathrm{~kg}$. These rather large variations of weight were not clearly associated with age.

Altogether 14 measurements of winter FHP were completed in 6 fawns at ambient temperature between 8 and $23^{\circ} \mathrm{C}$. In this range no relationship was found between metabolism and temperature. The mean

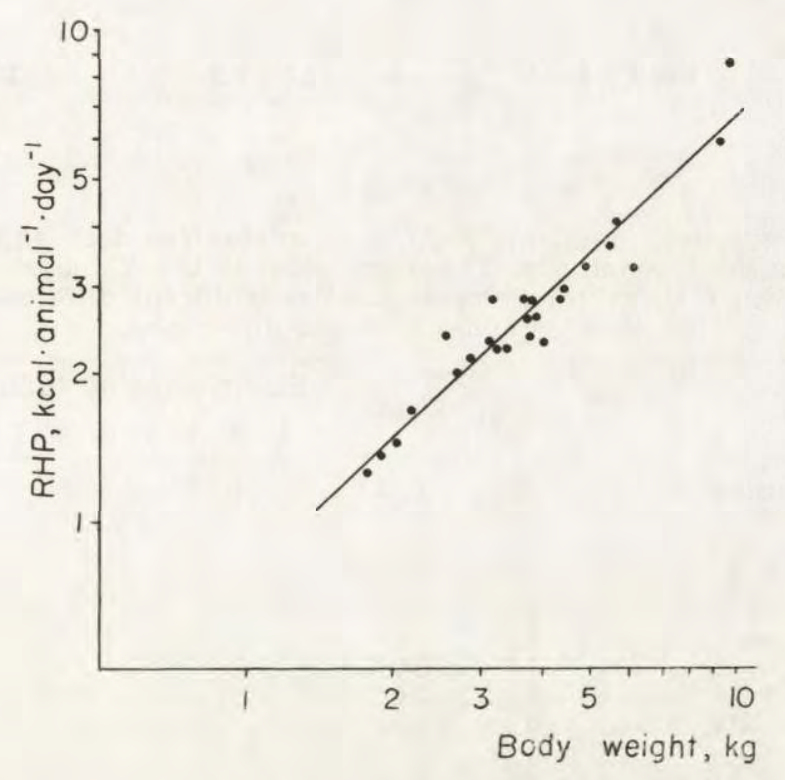

Fig. 8. Relationship between resting metabolism (RHP) of fawns and their body weight presented as the allometric function: $R H P=79.4 W^{0.9313}$.

body weight of individuals in this series of measurements was $14.0 \mathrm{~kg}$ $(13.0-15.0 \mathrm{~kg})$. FHP reached on the average $788.2 \mathrm{kcal} \times$ animal $^{-1} \times \mathrm{day}^{-1}$ $\left(109.9 \mathrm{kcal} \times \mathrm{kg}^{-0.75} \times\right.$ day $^{-1}$, Table 3$)$, hence it was higher by more than $20 \%$ from the mean winter FHP in adult animals $(p<0.001)$.

Resting metabolism (RHP) was measured in three non-fasted fawns (jointly 5 runs). Body weight of examined animals ranged from 11.5 to $13.0 \mathrm{~kg}$ (mean $12.6 \mathrm{~kg}$ ). The mean $R H P$ was $133.7 \mathrm{kcal} \times \mathrm{kg}^{-0.75} \times \mathrm{day}^{-1}$ (Table 3$)$, hence it exceeded fasting metabolism by almost $22 \%(0.001<$ $<p<0.01$ ). In the investigated range of temperatures no relationship between RHP and temperature was observed. 


\section{Respiratory Quotient (R. Q.)}

In all series of respirometric measurements the respiratory quotient (R. Q.) ranged from 0.71 to 0.95 ; on the average it was equal to $0.82 R$. $Q$. of fasted and non active animals was the lowest reaching in adult animals the mean value of 0.79 (Table 4). Locomotor activity caused increase of $R$. $Q$. to the mean value of 0.84 , the difference being statistically signifi-

Table 3

Metabolism of fawns in the age of 6 to 9 months (mean $\pm 95 \%$ confidence interval).

\begin{tabular}{cccc}
\hline Item & $\mathrm{kcal} \times \mathrm{animal}^{-1} \times \mathrm{day}^{-1}$ & $\mathrm{kcal} \times \mathrm{kg}^{-1} \times \mathrm{day}^{-1}$ & $\mathrm{kcal} \times \mathrm{kg}^{-0.75} \times \mathrm{day}^{-1}$ \\
\hline$F H P, \mathrm{~N}=14$ & $788.2 \pm 54.3$ & $57.1 \pm 4.7$ & $109.9 \pm 8.5$ \\
$R H P, \mathrm{~N}=5$ & $883.9 \pm 145.1$ & $71.2 \pm 9.2$ & $133.7 \pm 18.1$ \\
\hline
\end{tabular}

Table 4

Values of the respiratory quotient (R.Q.) obtained for roe deer and fawns during different experimental conditions. The right side of the Table shows significant differences between R.Q. values $(+=$ statistically significant difference at the level of $1 \%,-=$ non-significant difference).

\begin{tabular}{|c|c|c|c|c|c|c|c|c|c|c|c|c|c|c|}
\hline & \multirow{2}{*}{ Measurement } & \multirow{2}{*}{$\mathrm{N}$} & \multirow{2}{*}{ R.Q. } & \multirow{2}{*}{$\pm \mathrm{SD}$} & \multicolumn{10}{|c|}{ Significance of differences, $P<0.01$} \\
\hline & & & & & 1 & 2 & 3 & 4 & 5 & 6 & 7 & 8 & 91011 & 1112 \\
\hline 1 & $F H P$, ad., resting & 21 & 0.79 & 0.052 & & + & + & & & & & & & \\
\hline 2 & $F H P$, ad., active & 5 & 0.84 & 0.028 & & & & - & & & & & & \\
\hline 3 & $R H P$, ad , resting & 14 & 0.83 & 0.034 & & & & - & & & & & & \\
\hline 4 & $R H P$, ad., active & 11 & 0.86 & 0.045 & & & & & & & & & & \\
\hline 5 & FHP, ad., total & 26 & 0.80 & 0.052 & & & & & & + & 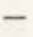 & & & \\
\hline 6 & $R H P$, ad., total & 25 & 0.84 & 0.040 & & & & & & & & - & & \\
\hline 7 & FHP, subad. & 16 & 0.82 & 0.032 & & & & & & & & - & & \\
\hline 8 & RHP, subad. & 5 & 0.82 & 0.031 & & & & & & & & & & \\
\hline 9 & $F H P$, all animals & 42 & 0.80 & 0.048 & & & & & & & & & + & \\
\hline 10 & $R H P$, all animals & 30 & 0.84 & 0.039 & & & & & & & & & & \\
\hline 11 & $R H P+R H P$, resting & 35 & 0.81 & 0.049 & & & & & & & & & & + \\
\hline 12 & $F H P+R H P$, active & 16 & 0.85 & 0.040 & & & & & & & & & & \\
\hline
\end{tabular}

cant $(p<0.001)$. The value of respiratory quotient was higher in RHP than in FHP measurements, amounting to 0.84 in adult animals, and 0.82 in half-year old fawns. At the same conditions of measurements no significant differences were observed in R.Q. of adult roe deer and fawns (Table 5).

\section{DISCUSSION}

Hitherto metabolism has been measured only in a few species of wild ruminants, including four species of deer: white-tailed deer (Odocoileus virginianus) (S ilve r et al., 1969, 1971; Thom p s on et al., 1973; $\mathrm{H}$ ol t e r et al., 1975), mule deer (Odocoileus hemionus) (Nor d a n et al., 1970), red deer (Cervus elaphus) (B r ockw a y \& M a loi y, 1967; M a - 
10 i y et al., 1968), and in two races of reindeer (Rangifer tarandus) (S e g a 1, 1962; M c E w a n, 1970). Metabolism was measured also in two species of African antelopes: eland (Taurotragus oryx) and wildebeest (Connochaetes taurinus) ( $\mathrm{R}$ ogerson, 1968), and in American pronghorn antelope (Antilocapra americana) (W e s le y et al., 1970, 1973). Comparison of the results obtained by these authors with own studies on roe deer will permit to describe a few general features of metabolism in wild ruminants.

Table 5

Fasting metabolism (FHP) in different species of wild ruminants (adults).

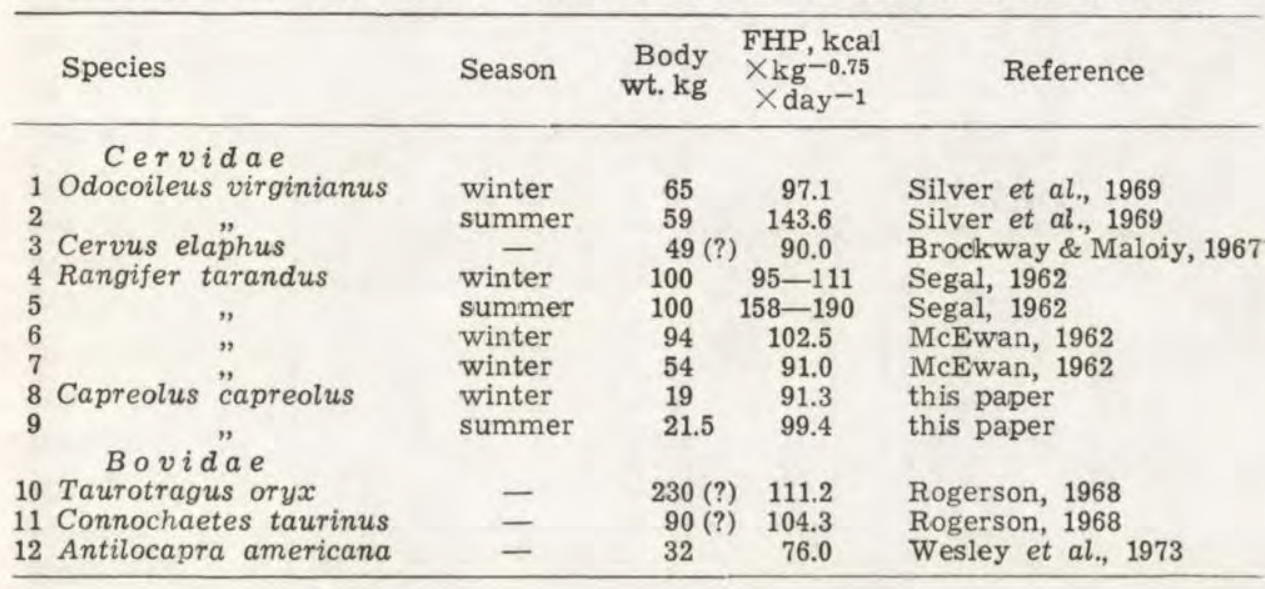

\section{Basal Metabolic Rate}

The measurement of the proper basal metabolism $(B M R)$ is practically impossible in wild ruminants, since standard conditions essential for such studies cannot be obtained. However, the lowest values of fasting metabolism (FHP) measured during rest and in the thermoneutral zone may represent a good approximation of $B M R$.

In roe deer the minimum value of FHP always exceeds the mean interspecies value given by $\mathrm{Kl}$ e i be $\mathrm{r}$ (1961). The lowest fasting metabolism in roe deer, occurring in winter, amounts to $91.3 \mathrm{kcal} \times \mathrm{kg}^{-0.75} \times{ }^{-1}$ and is very close to the values obtained by various authors for several species of wild ungulates (Table 5). In all examined species of wild ruminants fasting metabolism is conspicuously higher from the interspecies mean; this may be caused partly by an error of measurements since the results do not correspond exactly to basal metabolism. On the other hand, it cannot be excluded that increased metabolism is a characteristic feature of wild ungulates ( $\mathrm{M} \mathrm{cE}$ w a n, 1970). 
The results of measurements of minimum FHP in roe deer in various seasons indicate the occurrence of distinct seasonal rhythmicity. The lowest value of $F H P$ was found in winter and the highest during molting season (change of the coat) (Fig. 9). Seasonal rhythmicity of metabolism appears to be characteristic for deer. Silve r et al. $(1969,1971)$ observed in summer over $80 \%$ increase of metabolism in white-tailed deer. M c E w a n \& Whit e head (1970) discovered analogous variations (but of a smaller amplitude) in caribou (Rangifer tarandus), and $\mathrm{N}$ or da $\mathrm{n}$ et al. (1970) in young mule deer. S e g a 1 (1962) reported similar phenomena in Siberian reindeer (Table 5). In distinction to the above mentioned results Brockway \& Maloiy (1967) and Maloiy et al. (1968)

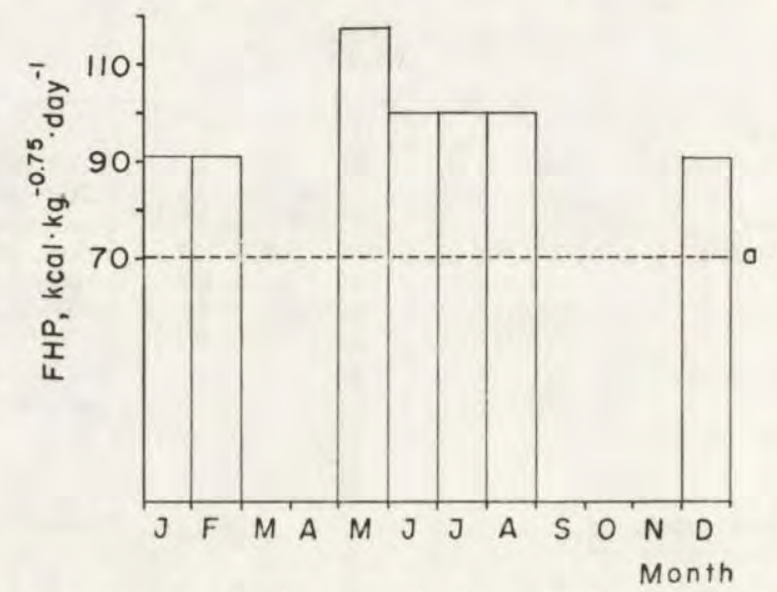

Fig. 9. Seasonal variations in fasting metabolism $(F H P)$ of roe deer; a - mean level of basal metabolism for homoiothermic animals: $B M R=70 W^{0.75}$ (K l e i b e r, 1961).

did not observe seasonal changes of metabolism in red deer (Cervus elaphus). Increase of metabolism in summer may be due to changes in the insulating properties of the coat (Silve r, 1969). Deteriorated insulating properties of the fur are probably responsible for increased metabolism of roe deer during change of the coat. On the other hand, $\mathrm{H}$ of $\mathrm{fman}$ \& Robins on (1966) demonstrated that the annual cycle of the hormonal system (pituitary, thyroid gland) directly affects metabolism of deer (Silver et al., 1969; Ozoga \& Verme, 1970).

\section{Costs of Thermoregulation}

In roe deer the increased heat production negatively correlated to ambient temperature was observed only in summer during measurements of fasting metabolism $(F H P)$. In the remaining seasons and in different 
experimental conditions ambient temperature had no significant effect on metabolism. The lower limit of the thermoneutral zone for roe deer falls for approximately $17^{\circ} \mathrm{C}$ in summer. Below this temperature metabolism increases linearly with decrease of temperature, and the slope of regression (equation 1) amounts to $-5.32 \mathrm{kcal} \times \mathrm{kg}^{-0.75} \times \mathrm{deg}^{-1}$. The literature is lacking any data for direct comparison of this value with other deer species. However, by utilizing the published measurements of FHP in summer in white-tailed deer (S i l v e r et al., 1971) it was possible to calculate the analogous regression for that species. In the range of temperatures from $-14^{\circ}$ to $+17^{\circ} \mathrm{C}$ the relationship between $F H P$ and ambient temperature shows in Odocoileus virginianus the slope of approximately $-5.1 \mathrm{kcal} \times \mathrm{kg}^{-0.75} \times \mathrm{day}^{-1} \times \mathrm{deg}^{-1}$, hence it is rather close to that found for roe deer. During winter measurements of metabolism of roe deer no additional heat production was observed since the animals were well acclimatized to the employed temperatures and were not tested below $0^{\circ} \mathrm{C}$. W e s le y et al. (1974) investigated on a rather limited material the relationship of $F H P$ and ambient temperature in the pronghorn antelope and described the regression slope as equal to $1.7 \mathrm{kcal} \times$ $\times \mathrm{kg}^{-0.75} \times$ day $^{-1} \times$ deg $^{-1}$. This last value refers to the animals adapted to very severe climatic conditions and is based on measurements during the whole year, including winter. It can be supposed that improvement of insulating properties of coat and seasonal adaptation causes also in the roe deer shifting the thermoneutral zone to lower temperatures and appeasement in the slope of regression of metabolism and temperature. This phenomenon could blur the effect of ambient temperature on metabolism in winter measurements. The results of determinations of winter metabolism in white-tailed deer in a very broad range of temperatures indicate that below $0^{\circ} \mathrm{C}$ metabolism increases by ca $2 \mathrm{kcal} \times \mathrm{kg}^{-0.75} \times$ day $^{-1} \times \operatorname{deg}^{-1}$ (S i lve $\mathrm{r}$ et al., 1969, 1971). Increase of metabolism due to calorigenic effect of food and costs of activity compensate totally the costs of thermoregulation. This effect may explain the lack of relationship between metabolism rate and temperature during measurements of RHP. Analogous relationships between metabolism rate and temperature were observed in white-tailed deer by $\mathrm{Holter}$ et al. (1975).

\section{Resting Metabolism (RHP) and Calorigenic Effect of Food (SDA)}

In all measurements of RHP, both in summer and winter, resting metabolism of non-fasted animals (RHP) exceeded by $25-30 \%$ analogous values of fasting metabolism (FHP). This difference represents calorigenic effect of food, in a broad meaning of this term, i.e. both "specific dynamic action « $(S D A)$, and metabolism of the flora of rumen (B la x ter,

2 - Acta theriologica 
1962; M a y a rd \& Loosli, 1962). The difference between RHP and FHP was slightly higher in summer than in winter, and this may be related to increased consumption and change in the chemical composition of food. This increase in heat production in non-fasting roe deer is similar to analogous measurements in other deer. $\mathrm{M} \mathrm{c} \mathrm{E} \mathrm{w} \mathrm{an} \mathrm{(1970)} \mathrm{estimat-}$ ed the difference between $F H P$ and $R H P$ in reindeer as almost $20 \%$, whereas S ilver et al. (unpubl. results) found $18 \%$ difference in summer and $11 \%$ difference in winter in white-tailed deer. After measuring metabolism in pronghorn antelope W e s le y et al. (1973) observed over $50 \%$ difference ( $20 \%$ consumed energy) betwen FHP and RHP. These latter results significantly deviate from other values reported in ruminant deer and may be explained by a different diet composition in antelopes.

\section{Energetic Costs of Locomotor Activity}

Preserving the upright postition was the most distinct level of spontaneous activity of roe deer. Energetic costs of such activity amounted to $1.1 \mathrm{kcal} \times \mathrm{kg}^{-0.75} \times \mathrm{hr}^{-1}(22 \%$ FHP $)$ - the value comparable with other data obtained for ruminants. The costs of standing approach in the sheep 9 to $11 \%$ of resting metabolism, according to different authors (B l a x ter, 1962; Brockway, 1965; Crampton \& Harris, 1969), in cattle 18-20\% (V e r c o e, 1973), in white-tailed deer approximately $20 \%$ of resting metabolism (Silver et al., unpubl.). In pronghorn antelope this cost was estimated as ca $1.9 \mathrm{kcal} \times \mathrm{kg}^{-1} \times \mathrm{hr}^{-1}$, or over $37 \%$ (W e sley et al., 1973). The remaining levels of spontaneous activity developed by roe deer in the metabolic chamber cannot be defined in a way enabling direct comparisons with other available data. T a y 1 or et al. (1970) estimated the energetic costs of movement at different speed in various animal species by employing the universal function:

$$
M_{r u n}^{\prime}=8.5 W^{0.60}+\frac{6.0}{V} \times W^{0.75}
$$

where: $M_{\text {run }}^{\prime}$ - costs of running the distance of $1 \mathrm{~km}$, cc $\mathrm{O}_{2} \times \mathrm{km}^{-1}$, $W$ - body weight in $\mathrm{g}, \mathrm{V}$ - speed of movements, $\mathrm{km} \times \mathrm{hr}^{-1}$. After comparison of increase of metabolism during moderate activity of roe deer in the respiratory chamber $(45-100 \%$ FHP) with the values of equation (6) solved for roe deer it can be stated that such increase corresponds to the movement of ca $1-2 \mathrm{~km} \times \mathrm{hr}^{-1}$, while intense activity in the chamber (increase of metabolism by $130-210 \%$ ) - to the speed of $2-4 \mathrm{~km} \times \mathrm{hr}^{-1}$.

Energetic costs of work in tamed reindeer were determined by $\mathrm{Hammel}$ (1962). Costs of standing of a $100 \mathrm{~kg}$ weighing animal amounted on the average to $132.8 \mathrm{kcal} \times \mathrm{kg}^{-0.75} \times \mathrm{day}^{-1}$, hence exceeded 
by approximately $30 \%$ resting metabolism determined in this species by other authors (McEwan, 1970; S e g a 1, 1962; Table 5). Pulling of a load by these animals required almost a fourfold increase of metabolism in comparison with that measured at standing position.

\section{Metabolism during Pregnancy and Lactation}

In a herd of roe deer reared in a large pen in Kraków Zoological Garden three successful pregnancies were observed during the period of investigations. However, only in one case the female was sufficiently tamed for carrying respirometric measurements. In order to reduce excitement of the doe a single measurement in early pregnancy and two runs during lactation were accomplished.

A single measurement of metabolism of a pregnant doe was carried out in the initial period of pregnancy. A small increase of metabolism observed in comparison with winter FHP in other adult roe deer cannot be unequivocally interpreted as additional costs of pregnancy. Analogous measurements in ruminant farm animals (cattle, sheep) indicate that during the initial period of pregnancy, where the growth of embryo is small, changes in the metabolism of a pregnanty female are barely perceptible (B laxter, 1962; Graham, 1965; Hafez \& Dyer, 1969; $\mathrm{S}$ a $1 \mathrm{~m}$ on - L e ga g n e u r, 1968).

Measurements of metabolism during lactation showed its considerable increase in comparison with non-lactating females (Table 2). The doe examined on 11th day of lactation was very annoyed by separation of fawns and during the whole run kept standing position. After making a suitable allowance for locomotor activity and calorigenic effect of food (lactating doe was of course not fasted!) it was possible to estimate the increase of heat production as approximately $881 \mathrm{kcal} \times \mathrm{animal}^{-1} \times \mathrm{day}^{-1}$. This strong overloading of the energy budget in the early period of lactation caused also a conspicuous decrease of body weight (by approximately $1.5 \mathrm{~kg}$ ). On 30th day of lactation the difference between resting metabolism of the lactating doe and analogous level of metabolism in other roe deer in the same season was only $285 \mathrm{kcal} \times \mathrm{animal}^{-1} \times \mathrm{day}^{-1}$. A gradual decrease of lactation is associated with lowered share of milk in the total diet of fawns, which rather early begin to utilize green feed.

\section{Metabolism of Fawns}

The metabolic rate of fawns during growth was strongly correlated in a linear way with body weight. Attempts of fitting this correlation with a rectilinear or doubly logarithmic equations gave almost identical results (equations (4) and (5)). A very similar result was obtained by 
McEwan \& Whitehead (1970) after measuring RHP in calves of caribou (Rangifer tarandus) during the initial period of growth: $R H P=75 \times W^{1.0}$. Nordan et al. (1970) reported several equations for different categories of age and sex of calves of mule deer (Odocoileus hemionus). For males in the age of 140 days this equation is $R H P=$ $80 \mathrm{~W}^{0.94}$, and for females $R H P=149 \mathrm{~W}^{0.75}$. Increase of body weight in calves of mule deer was accompanied by a less steep slope of regression which could reach even negative values ( $\mathrm{N}$ or dan et al., 1970). It appears that in fast-growing animals metabolism is more accurately described by linear function of body weight than by generally assumed allometric functions (B l a c k m o r e, 1969).

Measurements of RHP in roe deer fawns take into account also calorigenic effect of food and additional costs of metabolism associated with fast retention of biomass in that period. The metabolic rate of fawns shows a characteristic increase during the first few days of life with the maximum on 7 th day. Such shape of the curve of metabolic rate (Fig. 6) was described in young individuals of a few mammalian species, e.g. wild boar (M y r cha \& J e zierski, 1972), albino rat (K le i ber, 1961; Taylor, 1960), hamster (Rožaja \& Maslennikova, 1968). These changes are probably related with changes in growth rate, food composition and development of thermoregulation in young animals. Some further examples of this phenomenon are cited by A damsons et al. (1969).

Measurements of metabolism of fawns in the age of 6 to 9 months fell for winter. In this season apparent inhibition of growth is observed in deers (Wood et al., 1962; M c Ewan, 1968; Wood \& Cow an, 1969; B andy et al., 1970). However, Thomps on et al. (1973) found that in Odocoileus virginianus a slight retention of protein occurs being accompanied by decrease of fat reserves. This phenomenon takes place probably also in roe deer and it may be responsible for peculiar changes of metabolism in that period. FHP of fawns is slightly higher than the metabolism of adult individuals, perhaps due to costs of protein deposition. Winter FHP of fawns shows, moreover, a slight negative correlation with body weight, similarly to that observed on Odocoileus hemionus by Nordan et al. (1970). Rather limited material and too narrow range of body weight does not permit to present this relationship in examined roe deer in the form of a regression equation. Resting metabolism of half year old fawns was higher by $22 \%$ from fasting metabolism, hence the increase in heat production associated with food digestion was similar to that in adult individuals.

In half-year old fawns no increase of metabolism associated with thermoregulation was observed in the investigated range of temperatures. 
Bluzma (1967) reported that in four-month old fawns of roe deer the thermoregulation-dependent increase of fasting metabolism amounts to $1.7-2.5 \% \times \mathrm{deg}^{-1}$, and of $R H P$ - to ca $0.2-0.8^{0} \% \times \mathrm{deg}^{-1}$ (in ambient temperatures below $12^{\circ} \mathrm{C}$ ). However, these data are rather fragmentaric and poorly documented (the author did not give absolute values) hence they cannot be used for direct comparisons.

\section{Changes in R.Q.}

The oscillations of respiratory quotient within the range of $0.71-0.95$ observed in all series of respirometric measurements suggest that various substrates are catabolized during investigations of various metabolic states. The lowest R.Q. values (mean $0.79-0.81$ ), indicating a significant proportion of lipid metabolism, occurred in animals resting and fasting. An increase of R.Q. to the mean values of $0.83-0.84$ (Table 4) in well-fed animals results from metabolism of carbohydrates, which constitute the principal component of the roe deer diet. Still further increase of the respiratory quotient in active animals (up to 0.84 in fasted and to 0.86 in well-fed, Table 4) is caused probably by augmented utilization of carbohydrates (glucose) - the phenomenon characteristic for muscular work.

The evaluation of energy budgets of roe deer, taking into account various factors affecting energy requirements in natural conditions, is difficult. However, the results of respirometric measurements in the laboratory may constitute a good basis for construction of energy budgets (G e s s a man, 1973; Moe n, 1973). Analysis of such budgets by means of simulation in digital computers (W e in e r, 1975; W e in e r, in praep.) indicates that in roe deer particularly important is the knowledge of the fasting metabolism rate $(F H P)$ and resting metabolism rate $(R H P)$.

Acknowledgements: The author is grateful to Dr. W. Grodzin sk i for stimulating discussions during the experiments and to $\mathrm{Mr}$. S. Rojkowski for invaluable technical assistance.

\section{REFERENCES}

1. Adamsons K., Blumberg E. \& Joelson I., 1969: The effect of ambient temperature upon post-natal changes in oxygen consumption of the guinea pig. J. Physiol., 202: 261-269. London.

2. Bandy P. J., Cowan I. McT. \& Wood A. J., 1970: Comparative growth in four races of black-tailed deer (Odocoileus hemionus). Part I. Growth in body weight. Can. J. Zool., 48, 6: 1401-1410.

3. B lackmore O., 1969: Body size and metabolic rate in newborn lambs of two breeds. J. Appl. Physiol., 27, 2: 241-245.

4. Blaxter K. L., 1962: The energy metabolism of ruminants. Hutchinson: 1-329. London. 
5. Bluzma P., 1967: Termoregulacjonnyé adaptacii u kosul. Ref. Dokl. 3 Vsesojuzn. Sov. po Ekologičeskoj Fiziologii, Biochimii i Morfologii, Novosybirsk: $8-9$.

6. Bobek B., Drożdż A., Grodziński W. \& Weiner J., 1974: Studies on productivity on the roe deer population in Poland. Proc. XI Int. Congr. Game Biol.: 115-123. Stockholm.

7. Brockway J. M., 1965: Posturally associated changes in the heat content of sheep. [In: "Energy metabolism«, Ed. K. L. Blaxter], Academic Press: 395-404. London.

8. Brockway J. M. \& Maloiy B. M. O., 1967: Energy metabolism of the red deer. J. Physiol., 194: 22-24. London.

9. Cramption E. W. \& $\mathrm{Harris}$ L. E., 1969: Applied animal nutrition. Freeman Co.: 1-753. San Francisco.

10. Drożd ż A. \& Osiecki A., 1973: Intake and digestibility of natural feeds by roe deer. Acta theriol., 18, 3: 81-91.

11. Drożdż A., Weiner J., Gębczyńska Z. \& Krasińska M., 1975: Some bioenergetic parameters of wild ruminants. [In: "The role of large herbivorous mammals in functioning of woodland ecosystems «, Eds. W. Grodziński \& Z. Pucek], Pol. ecol. Stud. 1, 2: 85-101.

12. Eisfeld D., 1974: Protein requirements of roe deer (C. capreolus L.) for maintenance. Proc. XI. Int. Congr. Game Biol.: 133-138. Stockholm.

13. Elle nberg H., 1974: Beiträge zur Okologie des Rehes (Capreolus capreolus L.). Daten aus den Stammhamer Versuchsgehegen. Dissertation zur Erlangung des Doktorgrades der Matematisch-Naturwissenschaftlichen Fakultät der Christian-Albrechts Universität zu Kiel.: 1-134.

14. Gessaman J. A., 1973: Ecological energetics of Homeotherms. A view compatibile with ecological modeling. Utah State Univ. Press: 1-155. Logan.

15. Grah am N., McC., 1965: Metabolism of the pregnant ewe and some effects of thermal stress. [In: *Energy metabolism\&, Ed. K. L. Blaxter], Academic Press: 387-394. London-New York.

16. Grodziński W., 1975: The role of large herbivore mammals in functioning of forest ecosystems - a general model. [In: »The role of large hebivore mammals in woodland ecosystems«, Eds. W. Grodziński \& Z. Pucek], Pol. ecol. Stud. 1, 2: 5-15.

17. Hafez E. S. E. \& Dyer I. A. (Eds.), 1969: Animal growth and nutrition. Lea \& Febiger: 1-402. Philadelphia.

18. H a m mel H. T., 1962: Thermal and metabolic measurements on a reindeer at rest and in exercise. Tech. Doc. Rept. AAL-TDR 61-54, Arctic Aeromedical Lab. USAF, 1-34. Seattle.

19. Hart J. S., Heroux O., Cottle W. H. \& Mills J. A., 1961: The influence of climate on metabolic and thermal response of infant caribou. Can. J. Zool., 39: 845-856.

20. Hoffman R. A. \& Robinson P. F., 1966: Changes in some endocrine glands of white-tailed deer as affected by season, sex and age. J. Mammal., 47, 2: 266-280.

21. Holter J. B., Urban W. E., Jr. Ha yes H. H., Silver H. \& Scutt H. R., 1975: Ambient temperature effects of physiological traits of white-tailed deer. Can. J. Zool., 53, 6: 679-685.

22. Kleiber M., 1961: The fire of life. J. Wiley and Sons: 1-453. New York.

23. Maloiy G. M. O., Kay R. W. B. \& Goodal1 E. D., 1968: Studies on the 
physiology and digestion and metabolism of the red deer (Cervus elaphus). Symp. zool. Soc., London, 21: 101-108.

24. M a nard L. A. \& Loosli J. K., 1962: Animal Nutrition. McGraw-Hill: $1-613$. New York.

25. M c E w a n E. H., 1968: Growth and development of the barren-ground caribou. II. Postnatal growth rates. Can. J. Zool., 46, 5: 1023-1029.

26. M c Ewan E. H., 1970: Energy metabolism of barren-ground caribou (Rangifer tarandus). Can. J. Zool., 48, 2: 391-392.

27. McEwan E. H. \& Whitehead P. E., 1970: Seasonal changes in the energy and nitrogen intake in raindeer and caribou. Can. J. Zool. 48, 5: 905-913.

28. McEwan E. H. \& Whitehead P. E., 1971: Measurement of the milk intake of raindeer and caribou calves using tritiated water. Can. J. Zool., 44, 4: $443-447$.

29. Moen A. N., 1973: Wildlife ecology. An analytical approach. Freeman: 1-458. San Francisco.

30. Myrcha A. \& Jezierski W., 1972: Metabolic rate during the postnatal development of wild boars. Acta theriol., 17, 33: 443-452.

31. Nordan H. C., Cowan I. McT. \& Wood A. J., 1970: The feed intake and heat production of the young black-tailed deer (Odocoileus hemionus columbianus). Can. J. Zool. 48, 2: 275-282.

32. Ozoga J. J. \& Verme L. J., 1970: Winter feeding patterns of penned white-tailed deer. J. Wildl. Manage, 34, 2: 431-439.

33. Payne P. R. \& Wheeler E. P., 1968: Comparative nutrition in pregnancy and lactation. Proc. Nutr. Soc. 27: 129-138.

34. Rogers on A., 1968: Energy utilisation by the eland and wildebeest. Symp. zool. Soc., London, 21: 153-161.

35. Rožaja D. A. \& M a slennikova L. S., 1968: O voznikovenii himičeskoj termoregulacji u zolotistyh homjačkov v ontogeneze. Tr. In-ta Fizjol, im. Pavlova, 13: $277-282$.

36. Sa lmon-Legagne u r E., 1968: Prenatal development in the pig and some other multiparous animals. [In: "Growth and development of mammals «, Eds. C. A. Lodge \& G. H. Lamming], Butterwords: 158-191. London.

37. Segal A. N., 1962: Sutočnye i sezonnye izmenenija gazoenergetičeskogo obmena u severnego olenja $\mathrm{v}$ svjazi z ekologičeskimi uslovijami suščestvovanija. Voprosy ekologii, 6: 129-130.

38. Silver H., Holter J. B., Colovos N. F. \& Hayes H. H., 1969: Fasting metabolism of white tailed deer. J. Wildl. Manage, 33, 3: 490-498.

39. Silver H., Holter J. B., Colovos N. F. \& Hayes H. H., 1971: Effect of falling temperature on heat production in fasting white-tailed deer. J. Wildl. Manage, 35, 1: 37-46.

40. Taylor C. R., Schmidt-Nielsen K. \& Raab J. L., 1970: Scalling of energetic cost of running to body size in mammals. Am. J. Physiol., 219, 4: $1104-1107$.

41. T a ylor P. M., 1960: Oxygen consumption in the new-born rats. J. Physiol., 154: 153-168. London.

42. Thompson G. B., Holter J. B., Hayes H. H., Silver \& Urban W. E. Jr., 1973: Nutrition of white-tailed deer. I. Energy requirements of fawns. J. Wildl. Manage, 37, 3: 301-311.

43. Vercoe J. E., 1973: The energy cost of standing and lying in adult cattle. Br. J. Nutr., 30: 207-210. 
44. Weiner J., 1975: Model of the energy budget of an adult roe deer. [In: „The role of large herbivorous mammals in functioning of woodland ecosystems «, Eds. W. Grodziński \& Z. Pucek], Pol. ecol. Stud. 1, 2: 103-119.

45. Wesley D. E., Knox K. L. \& Nagy J. G., 1970: Energy flux and water kinetics in young pronghorn antelope. J. Wildl. Manage, 34, 4: 908-919.

46. Wesley D. E., Knox K. L. \& Nagy J. G., 1973: Energy metabolism of pronghorn antelope. J. Wildl. Manage, 37, 4: 563-573.

47. Wood A. J. \& C ow a n I. McT., 1969: Post-natal growth. [In: »A practical guide to the study of the productivity of large herbivores «, Eds. F. B. Golley \& H. K. Buchner], Blackwell Sci. Publ.: 106-113. Oxford.

48. $\mathrm{Z}$ a r J. H., 1974: Biostatistical analysis. Prentice Hall Inc.: 1-620. Engelwood Cliffs.

Accepted, May 3, 1976.

January WEINER

\section{METABOLIZM ENERGETYCZNY SARNY}

\section{Streszczenie}

Zbadano metabolizm energetyczny sarn używając respirometru systemu otwartego i specjalnej komory (Fig. 1). Poziom metabolizmu sarn jest podobny jak i u innych dzikich przeżuwaczy, chociaż wyższy niż średni międzygatunkowy dla ssaków. Metabolizm glodowy (FHP) wykazuje wahania sezonowe; jest najwyższy w okresie wiosennej zmiany sierści, nieco niższy latem, a najniższy zimą: 117,0, 99,4 i $91,3 \mathrm{kcal} \times \mathrm{kg}^{-0,75} \times \mathrm{doba}^{-1}$ (Tabela 1). W okresie wiosny i lata metabolizm wzrasta ze spadkiem temperatury: $F H P\left(\mathrm{kcal} \times \mathrm{kg}^{-0,75} \times\right.$ doba-1) $=181,5-5,32 \mathrm{t}$, gdzie $t={ }^{\circ} \mathrm{C}$, (Fig. 2), W okresie zimy metabolizm jest skorelowany $\mathrm{z}$ ciężarem ciała: $F H P$ $\left(\mathrm{kcal} \times\right.$ zwierzę $^{-1} \times$ doba $\left.^{-1}\right)=193,6 W^{0,51}$ (Fig. 3). Metabolizm spoczynkowy zwierząt niegłodzonych $(R H P)$ osiąga latem 129,8 , a zimą $113,8 \mathrm{kcal} \times \mathrm{kg}^{-0,75} \times \mathrm{doba}^{-1}$ (Tabela 2), a więc jest wyższy od FHP o 25-30\%. Różnica ta reprezentuje ciepłotwórcze działanie pokarmu (SDA). Aktywność ruchowa powoduje podwyższenie metabolizmu o 9-210\%, przy czym koszt utrzymania pozycji stojącej wynosi $1,1 \mathrm{kcal} \times \mathrm{kg}^{-0,75} \times$ godz. $^{-1}$ (Fig. 4). Wzrost metabolizmu w początkowym okresie ciąży jest nieznaczny, jednak w okresie intensywnej laktacji (11 i 30 dzień) metabolizm wzrasta aż do wartości 226,6 i 152,2 kcal $\times \mathrm{kg}^{-0,75} \times$ doba $^{-1}$ (Tabela 3). Metabolizm spoczynkowy koźląt do 80 dnia życia jest skorelowany liniowo z ciężarem ich ciała $(W, \mathrm{w} \mathrm{kg}): R H P=73,53 \times W$ (gdzie $R H P$ w kcal $\times$ zwierzę ${ }^{-1} \times \mathrm{doba}^{-1}$ ), Fig. 7 i 8. RHP osiąga najwyższe wartości w 7 dniu życia (Fig. 6). U koźląt 6-9-miesięcznych FHP osiąga $109,9 \mathrm{kcal} \times \mathrm{kg}^{-0, .75} \times$ doba-1, zaś $R H P$ jest wyższy o około $22 \%$ (Tabela 4). Współczynnik oddechowy (R.Q.) we wszystkich pomiarach wynosił średnio 0,82 , przy czym wartości najniższe $(0,79)$ przybierał u zwierząt głodzonych $\mathrm{i}$ w spoczynku, a najwyższe $\mathrm{u}$ aktywnych zwierząt niegłodzonych $(0,86)$, Tabela 5. Metabolizm sarn wykazuje podobne cechy jak u innych gatunków jeleniowatych: jest wyższy od średniej międzygatunkowej i zmienia się w cyklu rocznym (Tabela 6, Fig. 9). 